\title{
"CULTURAL" OR "KULTURNICHESKY" POPULISM? (ON THE MEANING OF CONCEPTS IN THE HISTORY OF RUSSIAN POPULIST STUDIES)
}

\author{
Gennadiy Nikolaevich Mokshin \\ Doctor of Sciences (History), Professor, \\ Department of Russian History, \\ Voronezh State University \\ mok410@mail.ru \\ Universitetskaya Sq., 1, 394006 Voronezh, Russian Federation.
}

\begin{abstract}
The article is devoted to the origin and content of the concept of "cultural" and "kulturnichesky" populism in the Russian populist studies.

Both terms appeared in the early twentieth century to refer to the right wing of the liberal populism. But they reflect different interpretations of the populist ideology: wide (of populism) and narrow (of marxism). The term "cultural populism" (originated from "cultural work") reflects the desire of right-wing populists to create sociocultural prerequisites for changing the existing social order. The term "kulturnichesky populism" (from the German "kulturträger"), by the recognition of the Marxists themselves, was designed to discredit the populist program of social work in the countryside, allegedly aimed at reconciliation with reality.

Most modern scholars following the tradition continue to use the concept of "kulturnichesky populism" and "cultural work", sharing their biased interpretation. Not by chance in the scientific and educational literature, culturalpopulism direction is still associated with indifference with respect to political life and at the same time petty-bourgeois liberalism. According to the author, this approach not only distorts the ideas of populists-uplifters but also diminishes their contribution to the development of populist ideas of 1880-1890s. Therefore, for specialists in the history of legal populism it is recommended to use a more correct terms "cultural populism" and "cultural work".
\end{abstract}

Key words: populist studies, populism, kulturnichestvo, "cultural populism", "cultural work", theory of "small deeds".

Дата поступления статьи: 28.10.2015

ББК 63.3(2)522-414.13

\section{«КУЛЬТУРНОЕ» ИЛИ «КУЛЬТУРНИЧЕСКОЕ» НАРОДНИЧЕСТВО? (О ЗНАЧЕНИИ ПОНЯТИЙ В ИСТОРИИ ОТЕЧЕСТВЕННОГО НАРОДНИКОВЕДЕНИЯ)}

\section{Геннадий Николаевич Мокшин}

Доктор исторических наук, профессор кафедры истории России, Воронежский государственный университет mok410@mail.ru Университетская пл., 1, 394006 г. Воронеж, Российская Федерация

Аннотация. Статья посвящена происхождению и содержанию понятий «культурное» и «культурническое» народничество в отечественном народниковедении.

Оба термина появились в начале XX в. для обозначения правого крыла легального народничества, но отражают различные интерпретации его идеологии: широкую - народническую и узкую - марксистскую. 
Термин «культурное народничество» (от «культурная работа») акцентирует внимание на стремлении народников к созданию социокультурных предпосылок для изменения существующего общественного строя. Термин «культурническое народничество» (от немецкого «kulturträger»), по признанию самих марксистов, должен был дискредитировать народническую программу социальной работы в деревне, якобы направленную на примирение с действительностью.

Большинство современных исследователей по сложившейся традиции продолжают использовать понятия «культурническое народничество» и «культурническая работа», вполне разделяя и оправдывая их заведомо предвзятое толкование. Неслучайно в научной и учебной литературе культурно-народническое направление по-прежнему ассоциируется с аполитизмом и мелкобуржуазным либерализмом. По мнению автора, этот подход не только искажает идеи народников-культурников, но и умаляет их вклад в развитие народнической мысли 1880-1890-х гг., поэтому для специалистов по истории легального народничества рекомендуется употребление более корректных терминов «культурное народничество» и «культурная работа».

Ключевые слова: народниковедение, народничество, культурничество, «культурное народничество», «культурная работа», теория «малых дел».

В современную российскую историографию понятия «культурное» и «культурническое» народничество вошли на рубеже 19801990-х годов. В то время среди исследователей пробудился интерес к истории правого крыла легального (либерального) народничества - сторонников мирной культурно-просветительской деятельности интеллигенции в деревне. Благодаря трудам В.И. Харламова, Б.П. Балуева, В.В. Зверева идеология и практика народников-культурников впервые получила более широкое и объективное освещение. Появилась возможность по-новому взглянуть и на всю историю классического русского народничества 1860-1890-х годов. Например, М.Ю. Лачаева предложила рассматривать ее как последовательную эволюцию от просвещения к террору и затем возвращение после тяжелых потерь к социокультурной деятельности [14, с. 337].

Однако к середине 2000-х гг. в научной и учебной литературе о правом народничестве утверждается другой подход. «Культурническое» течение окончательно признается тупиковой ветвью в развитии легально-народнической мысли. Дело в том, что так называемая «реабилитация» культурничества изначально носила половинчатый характер. Исследователи признавали определенный вклад культурников в «цивилизацию» России, но в их споре с народниками-политиками (сторонниками неотложных политических преобразований) победу отдавали последним. Сама идеология культурничества сводится к теориям «малых дел» и «среднего человека», которые к середине 1890-х гг. потеряли былую популярность [19, с. 69-70]. Очевидно, что мы по-прежнему имеем дело с марксистским подходом к интерпретации истории «культурного народничества», хотя и без откровенного очернительства в ее оценках. Об этом, в частности, свидетельствует общепринятая трактовка терминов «культурническое народничество», «культурническая работа», «культурничество» и т. п.

Все это заставляет нас обратиться к изучению этимологии этих понятий и проследить эволюцию их содержания от истоков до современности. К сожалению, до сих пор этот вопрос не привлекал внимание исследователей. Да и общая историография легального народничества еще ждет своего исследователя.

Интересующие нас термины «культурное» и «культурническое» народничество синонимы. Они обозначают одно и то же направление в легальном народничестве и происходят от одного корня - «культура». Действительно, акцент на необходимости культурной деятельности в народе (для подъема его умственного и нравственного уровня с целью развития самодеятельности и инициативы и превращения в самостоятельную силу общественного развития) - это то, что отличало культурников от политиков. Однако это не самоназвания культурных народников.

Оба термина появились только в начале $\mathrm{XX}$ в., когда данная ветвь народничества уже прекратила существование. Следовательно, можно предположить, что разные названия отражают различные интерпретации явления культурничества (широкое и узкое). Попробуем это доказать, отталкиваясь от двух базовых понятий: «культурная» и «культурническая» работа. 
Словосочетание «культурная деятельность» возникло в среде революционного народничества на рубеже $1870-1880-$ х гг. в контексте споров «деревенщиков» и «политиков». Странного здесь ничего нет. В 1870 -е гг. многие революционеры работали в деревне под видом учителей, врачей, фельдшеров, волостных писарей и т. п. По свидетельству О.В. Аптекмана, это была «подготовительно-революционная» «культурная работа», так как «верховным принципом нашей многосторонней культурной деятельности была революция» [2, c. 345]. Понятно, что будущие народовольцы с этим категорически не согласны. «Какие вы революционеры! Вы просто культурники», возражал им Андрей Желябов на съезде землевольцев в Воронеже в июне 1879 г. [29, c. 251]. Правда, документального подтверждения этой цитаты мы не нашли. Но тот же чернопеределец Аптекман в известном «Письме к бывшим товарищам» (1879 г.) употребляет слово «культуртрегеры» (от немецкого «kulturträger» - носитель культуры), а по-русски «культурники», также противопоставляя их «революционерам» [2, с. 429].

Полемика о том, чем революционно-культурная деятельность отличается от простого культуртрегерства, ускорила формирование так называемого культурно-народнического направления. Его становление началось после неудачного «хождения в народ». В статьях П.П. Червинского и И.И. Каблица - первых теоретиков данного течения - обосновывается необходимость для России армии мирных работников, способных возродить культурную самобытность народа. Однако удачное название для этой деятельности - «культурная работа» - придумали не они и даже не главный ее пропагандист 1880-х гг. Я.В. Абрамов, а народовольцы [25, с. 194]. И в широкое употребление его введут в начале 1890-х гг. идейные противники культурников - русские марксисты [24, с. 240].

Почему так получилось, сказать трудно. Возможно все дело в том, что «культуртрегерство» было одним из лозунгов тогдашних либералов, а либерализм и народничество - две полярные общественные доктрины. По крайней мере, в 1880-е гг. правое крыло легального народничества («народники-самобытники») еще больше «поправело», сбли- жаясь с почвенниками и толстовцами. Неслучайно главными критиками теории «малых дел» выступят либералы. Они же первыми обвинят народников-восьмидесятников в пренебрежительном отношении к европейской культуре и ее главному проводнику в России интеллигенции [27, с. 702, 728, 730].

В 1890-е гг. у народников-культурников появятся еще более строгие критики - русские марксисты. Их озабоченность успехом нового деполитизированного хождения интеллигенции «в народ» вполне понятна. «Исчезновение новой революционной идеи в период 80-х гг. в русском обществе, - читаем мы в первом политическом заявлении В.И. Ленина, - вызвало распространение убеждения, что падение абсолютизма зависит от культурного развития страны, что наиболее верный путь к его низвержению - это развитие культурных сил страны. Оппозиционный элемент пошел по пути культурной деятельности» [5, с. 366].

Эти строки написаны молодым Лениным между 1890-1893 гг. от имени группы народовольцев. После окончательного перехода в лагерь марксистов его отношение к народникамкультурникам заметно ожесточится. В 1894 г. в книге «Что такое друзья народа...?» он вводит в обращение термины «культурнический оппортунизм» и «примирительная культурническая деятельность» [15, с. 282, 283, 294, 297$].$ А это уже производные не от почтенной для всех народников «культурной работы» (необходимого условия построения социализма), а от «буржуазного» слова «культурник», то есть «культуртрегер»- по понятиям радикалов, распространитель «мелкой» мещанской культуры.

Примерно в то же время в марксистской литературе появляется еще один термин «культурничество» [4, с. 30]. Формально - это калька с немецкого «культуртрегерство» (культурно-просветительская работа в массах в отрыве от политики). На самом деле-попытка еще раз уличить народников в либеральном перерождении их доктрины после 1881 года. Заметим, что понятие «либеральные народники» В.И. Ленин придумает только в 1897 году.

Для современного читателя термины «культурничество» и «культурнический» не содержат какого-либо подтекста, тем более негативного. Но вот откровение Л.Д. Троцко- 
го начала 1920-х гг., посвятившего культурничеству несколько специальных работ: «Слово “культурничество" имело до революции в наших устах уничижительныц̆, почти что бранный характер (курсив мой. - Г. М.). “Это, мол, культурник”, то есть деятель, который мелко плавает. Были ли мы правы тогда? Да, были. Потому что в условиях царизма и в условиях буржуазного господства самая главная культурная работа должна была состоять в том, чтобы сплотить пролетариат для завоевания власти, ибо только завоевание власти открывает возможность настоящей широкой культурной работы» [30, с. 180].

Итак, если верить Ленину и Троцкому, все народники-культурники были «малоделами», то есть сторонниками теории «малых дел». Отсюда и «уничижительный» смысл слова «культурнический» применительно к их деятельности, которая была «бесплодна, как песок в пустыне».

В действительности многие «малые дела» народников не так уж и малы. Особенно когда они получали поддержку правительства (например, в деле организации народного кредита). Известно также, что в начале 1890-х гг. с теорией широкой, «органической» «культурной работы» выступил видный народнический теоретик С.Н. Кривенко. Ее суть заключалась в стремлении согласовать политику и экономику, свободолюбивые устремления прогрессивной интеллигенции и практическую деятельность по удовлетворению нужд народных масс. По убеждению народника, общественные деятели, боровшиеся за утверждение в стране новых общественных учреждений, не должны были препятствовать тем, кто стремился к частным улучшениям народной жизни путем развития общественного самоуправления. Разъединение практиков, занятых конкретным делом, и теоретиков, стремящихся к постановке широких общественных задач, вело к двойной трате сил $[13$, c. 173,174$]$.

К сожалению, попытка примирения сторонников «малых» и «больших» дел не была поддержана не только либералами и марксистами, но и лучшим другом С.Н. Кривенко Н.К. Михайловским - самым авторитетным народником 1890-х гг., перешедшим к тому времени на позиции «либерального социализ- ма». В результате в 1894 г. журнал «Русское богатство», где печатались культурники, раскололся, а сами они очень быстро оказались на обочине русского освободительного движения [18, с. 141-144].

С.Н. Кривенко скончался в 1906 году. С этим печальным событием и связано появление (в одном из некрологов) понятия «культурное народничество», поскольку покойный был наиболее ярким представителем этого направления [12]. В 1908-1910-х гг. биография и взгляды Кривенко получили отражение в серии статей Е.Д. Максимова. «Культурную работу» он рассматривал как лучшее вспомогательное средство к общей работе по обновлению социального и политического строя России и как лучший способ подготовки масс к осуществлению тактической формулы народничества - «все для народа и только через народ». С этой точки зрения разрабатываемые Кривенко программа и тактика реформирования русской жизни не имели ничего общего ни с толстовством, ни с «пресловутой» теорией «малых дел» Якова Абрамова - так называемой «абрамовщиной» $[16$, стб. 49, 51, 54].

Из ненародников самую высокую оценку «культурному» движению 1890-х гг. дал правый меньшевик А.Н. Потресов, заметивший в нем «начатки политического воспитания масс культурных работников». Но и он призывал не смешивать это широкое общественное движение, охватившее общество после голода 1891-1892 гг., с «малыми делами» публицистов «Недели» - порождением реакции 1880-х гг. [26, с. 172].

В начале XX в. правое крыло легального народничества определенного названия так и не получило. Помимо «культурного народничества», его именовали «культурно-народническим», «ортодоксальным», «недельным» (в 1880-е гг. газета «Неделя» - его главная цитадель) и т. п. Общим было признание в нем направления, лишь отчасти окрашенного народничеством [10. с. 19]. С другой стороны, отмечалось, что на почве так называемой «культурной работы» начался процесс сближения между «элементами» земства и демократической интеллигенцией, которые вместе противостояли напору администрации [23, с. 539]. 
Более жесткая оценка культурной деятельности народников (как «культурного крохоборства») начинает насаждаться после 1917 г. в связи с разработкой канонической истории большевистской партии. Но монополия на истину появилась у марксистов только в 1930-е годы.

В 1920-е - начале 1930-х гг. понятие «народники-культурники» включало не только поздних народников, но и участников ряда народнических кружков 1870-х гг. (лавристы, чайковцы, долгушенцы), чья революционность требовала специальной оговорки [35, с. 32]. Сам П.Л. Лавров долгое время считался идеологом мирного народничества, хотя деятельности «почтенных» культурников (заведению школ и больниц, развитию кооперации и т. п.) он всегда давал скептические оценки [17, стб. 175].

В 1926 г. Аптекман опубликовал статью о П.П. Червинском под названием «Зачатки культурного народничества в 70-х годах». Эта статья интересна не только тем, что зарождение его идеологии относилось к середине 1870-х гг., а не к эпохе «малых дел». Важнее, что сама идеология была названа «типичной народнически-социалистической» [1, с. 35]. Марксисты это категорически отрицали.

Перелом в отношении к «архиправому» народничеству происходит в начале 1930-х гг. с окончательным утверждением в обществоведческой литературе ленинской терминологии, в том числе и понятия «культурническое народничество» [6, с. 11]. («Культурным» оно останется лишь в зарубежном народниковедении [11, с. 177]). Но использовалось оно достаточно редко, так как изучением данного течения больше никто не занимался. С конца 1930-х гг. «культурническое» народничество практически растворилось в «либеральном».

Возрождение интереса к народничеству в конце 1950-х гг. и значительные успехи в его изучении в 1960-1970-е гг. критического отношения к «культурничеству» не изменили. Ведь изучалось только революционное народничество 1870 - начала 1880-х гг., причем в рамках ленинской его концепции. В то же время из литературы исчезло понятие «революционное культурничество», и «культурниками» теперь назывались публицисты газеты «Неделя» и их последователи [28, с. 79,82$].$
Специальным предметом анализа взгляды теоретиков этой главной цитадели правого крыла «либерального» народничества стали на рубеже 1970-1980-х гг. в диссертации В.И. Харламова. Проанализировав труды своих предшественников, историк первым обратил внимание на нетождественность понятий «культурничество» и «теория малых дел» [33, с. 110]. Впрочем, тезис о том, что первое из них было шире второго (так как не все культурники разделяли упомянутую теорию), развития у него не получил.

Именно Харламов дал второе рождение терминам «культурное» и «культурническое народничество», которые давно уже вышли из употребления [31, с. 9; 33, с. 110]. При этом второе из них употреблялось гораздо чаще, став базовым и для самого ученого, и для его последователей.

Харламов подробно изучил историю зарождения культурнической тенденции в народничестве, отодвинув ее к концу 1860 -х годов. Он же установил, что первым идеологом культурничества следует считать не П.П. Червинского и тем более не Я.В. Абрамова, а И.И. Каблица - самого крупного представителя этого направления. Кроме того, Харламов значительно расширил круг народников-культурников и ввел в широкое употребление понятие «второе хождение» интеллигенции в народ (для устранения последствий голода 1891-1892 гг.) [34, с. 178, 180]. Правда, по факту оно было третьем. Второе массовое «хождение» организовали землевольцы в конце 1870-х годов.

В то же время в оценках культурничества молодой историк по понятным причинам остался верен устоявшейся марксистской традиции. «...Сама по себе культурническая работа народолюбивой интеллигенции в деревне $<\ldots>$ не являлась реакционной. Напротив, - эта работа $<\ldots>$ отражала демократические устремления широких слоев рядовой русской интеллигенции. Теория малых дел (по Харламову, это ядро культурничества. - Г. М.) была демократической постольку, поскольку ориентировала народолюбивую интеллигенцию на помощь крестьянству в его повседневной борьбе за свое существование, и она же была реакционной постольку (и тогда), поскольку (когда) выс- 
тупала в качестве социалистической доктрины с претензией решить коренные социальные проблемы страны, поскольку о б ъ е к т и в н о уводила широкие народные массы с пути революционного преобразования общества» [31, c. 18].

На рубеже 1980-1990-х гг., когда марксистская парадигма затрещала по швам, Харламов несколько смягчил свои оценки. В приведенной выше цитате «реакционная» культурническая работа стала «консервативной» $[34$, c. 182]. Но трактовка ее содержания осталась прежней - либеральное культурничество на почве почти победившего в России капитализма.

Исследования Харламова оказали существенное влияние на становление современной российской историографии культурно-народнического направления. Первые обобщающие монографии по истории правого народничества Б.П. Балуева и В.В. Зверева, увидевшие свет в середине 1990-х гг., - это развитие концепции «недельного» «культурнического» народничества, предложенной В.И. Харламовым. При этом Балуев сделал упор на присущий всем либеральным культурникам аполитизм, а Зверев на их отказ (на излете 1880-х гг.) от социалистической перспективы. И оба автора связали дальнейшую эволюцию правонароднической мысли (в 1890-е гг.) с деятельностью Н.К. Михайловского и его «литературной семьи» $[3$, с. 257-259; 8, с. $363-$ 365]. Учение С.Н. Кривенко об «органической культурной работе», ориентированное на социалистический идеал, было просто проигнорировано. По признанию Харламова, «современный исследователь не найдет в трудах Кривенко принципиально новых положений, обогативших либерально-народническую доктрину» [32, с. 706]. Их и не искали.

В 1997 г. ведущий исторический журнал «Отечественная история» опубликовал «сочувственную» статью С.Я. Новака о «пионере» теории «малых дел» Я.В. Абрамове. В «культурнической» деятельности народников автор обнаружил много «жизненного смысла». Однако вслед за Зверевым он отказался включить культурников в славную когорту наследников идей 1860-1870-х гг., то есть признать их продолжателями народнической социалистической традиции. И это при том что основу мировоззрения Абрамова, по словам Новака, составляла идея о потенциальной способности народа к самоорганизации на социалистических началах, а планируемые им практические меры помощи народу должны были привести к постепенному изменению жизни людей и построению социально справедливого общества [21, с. 82-84].

На рубеже 1990-2000-х гг. в отечественной историографии окончательно утверждается интерпретация правого (реформаторского) народничества как идеологии самобытной модернизации России. Вомногом это заслуга В.В. Зверева, ставшего к тому времени ведущим отечественным народниковедом - неизменным автором статей о народничестве в российских энциклопедиях. А вместе с его концепцией эволюции народничества 1870-1890-х гг. в современную научную и учебную литературу проникает представление о «культурническом» течении как о чем-то узком, второстепенном, отупившем от истинного пути к заветной цели. По сути, это возрождение марксистских оценок позднего народничества только в усеченном виде. Теперь «истинное» лицо правого народничества олицетворяют не Каблиц, Абрамов и Кривенко, а Михайловский и его идейное окружение [9, c. $276 ; 10$, c. 235$]$.

В начале статьи мы упомянули о существовании альтернативного взгляда на место в истории народничества культурно-просветительской деятельности (озвученного М.Ю. Лачаевой). У истоков широкой интерпретации «культурной работы» стоял первый биограф С.Н. Кривенко - Е.Д. Максимов, который в начале XX в. и сам был известным теоретиком и практиком культурничества.

По Максимову, глубинный смысл культурной работы заключался в идее подготовки нового народно-социалистического строя параллельно с разрушением старого - буржуазного. По большому счету этой деятельностью занимались все народники (от Н.Г. Чернышевского до Н.К. Михайловского). Одни из них работали над подъемом благосостояния и общей культуры народа, другие посвятили себя «культурной работе высшего порядка»проведению в жизнь отдельных начал будущего строя [16, стб. 41, 55].

Разработку теории «органической культурной работы» Е.Д. Максимов приписывал 
С.Н. Кривенко, с чем можно и поспорить. О необходимости сочетания усиленной «прогрессивной» работы со «статической» (удовлетворение повседневных нужд общественного организма в питании, образовании и т. п.) еще в 1880 г. писал ныне почти забытый народник-культурник Л.Е. Оболенский [22, c. 244]. Главная заслуга Евгения Максимова - в новой типологии легального народничества 1890-х гг. - выделении в нем не только правого (И.И. Каблиц) и левого (Н.К. Михайловский) крыла, но и центристской группы во главе с В.П. Воронцовым и С.Н. Кривенко [18, с. 11-12].

В современном народниковедении идеи первого историка «культурной работы» получили развитие в трудах Г.Н. Мокшина. Он также доказывает неоднородность культурнонароднического течения, разделяя его на узких культурников - сторонников концепции социальных преобразований страны и тех, кто признавал необходимость завоевания широких политических свобод, но на почве борьбы за удовлетворение насущных народных нужд (концепция социально-политических преобразований). В монографии, посвященной идейной эволюции легального народничества, исследователь пришел к выводу о том, что «культурничество» С.Н. Кривенко и В.П. Воронцова, пытавшихся объединить приверженцев «малых» и «больших» дел, - это не побочная ветвь развития легально-народнической мысли, а существенный шаг вперед по пути преодоления противоречий между социальной и политической концепциями общественных преобразований и выработки нового (надпартийного, надклассового) типа мышления и действия [20, с. 288].

Еще одно направление современной историографии культурничества представлено в монографии И.А. Гордеевой. В отличие от других исследователей она изучала эту тему в контексте истории российского коммунитарного движения. По мнению исследовательницы, культурничество - это особое течение в народничестве, элементы которого были присущи и революционным и «либеральным» народникам. Гордеева убедительно показала, что движение образованных людей «на землю» (названное ею коммунитарным) выражало стремление определенной части образован- ного общества к нравственному самосовершенствованию, мыслимому за основной способ улучшения общественных отношений, альтернативный революционному. И хотя далеко не все коммунитарии разделяли теорию «малых дел», с правыми народниками их объединяло общее сочувствие культурничеству в самом широком смысле этого слова. Наиболее известным народником-коммунитарием был А.Н. Энгельгардт [7].

Обобщая историю возникновения и эволюции понятий «культурное» и «культурническое» народничество в отечественном народниковедении, можно сделать следующие выводы.

Во-первых, оба термина появились только в начале XX в. в историографии позднего народничества и до сих пор употребляются сравнительно редко, так как обозначают лишь одно из течений легального народничества, причем не самое известное и изученное. Потому их следует отнести к разряду узкопрофессиональных.

Во-вторых, они имеют разное происхождение и значение. «Культурное народничество» связано с понятием «культурная работа» в чисто народнической ее интерпретации (как деятельность по созданию социокультурных предпосылок для постепенного изменения существующего общественного строя). Термин «культурническое народничество» происходит от немецкого «культуртрегер», то есть «культурник». Он введен в оборот русскими марксистами для дискредитации якобы «оппортунистической» программы позднего народничества, направленной на примирение с действительностью.

В-третьих, современные исследователи по сложившейся традиции предпочитают использовать термины «культурническое народничество» и «культурническая работа», вполне разделяя и оправдывая их марксистскую (заведомо тенденциозную) интерпретацию. Неслучайно в научной и учебной литературе культурно-народническое направление по-прежнему ассоциируется с аполитизмом и мелкобуржуазным либерализмом. Поэтому для специалистов по истории легального народничества предпочтительно употребление более корректных терминов «культурная работа» и «культурное народничество». 
В-четвертых, понятия «культурник» и «культурничество» тоже применимы к истории правого народничества. Но при их употреблении следует уточнять, о чем идет речь: об узком культурничестве публицистов газеты «Неделя», сознательно дистанцировавшихся от политики и социального радикализма, или о народниках-центристах 1890-х гг., допускающих наряду с «малыми делами» социальные эксперименты по проведению в жизнь отдельных начал будущего строя и борьбу за политические свободы.

\section{СПИСОК ЛИТЕРАТУРЫ}

1. Аптекман, О. В. Зачатки культурного народничества в 70-х годах (кружок студентов Земледельческого института) / О. В. Аптекман // Историко-революционный сборник. - М. ; Пгр. : Госиздат, 1924. - T. 1. - C. 9-36.

2. Аптекман, О. В. Общество «Земля и воля» 70-х гг. По личным воспоминаниям / О. В. Аптекман. - Пгр. : Колос, 1924. - 460 с.

3. Балуев, Б. П. Либеральное народничество на рубеже XIX-XX веков : монография / Б. П. Балуев. - М. : Наука, 1995. - 267 с.

4. [Богданович, А. И.] Насущный вопрос. Лондон : Издание Лондонского фонда вольной русской прессы, 1895. -32 с.

5. Будницкий, О. В. Терроризм в российском освободительном движении: идеология, этика, психология (вторая половина XIX - начало XX века) : монография / О. В. Будницкий. - М. : РОССПЭН, 2000. $-399 \mathrm{c}$.

6. Буш, В. В. Очерки литературного народничества 70-80-х гг. / В. В. Буш. - М. ; Л. : Худож. литpa, 1931. $-162 \mathrm{c}$.

7. Гордеева, И. А. «Забытые люди». История российского коммунитарного движения : монография / И. А. Гордеева. - М. : АИРО-ХХ, 2003. - 240 с.

8. Зверев, В. В. Реформаторское народничество и проблема модернизации России. От сороковых к девяностым годам XIX в. : монография / В. В. Зверев. - М. : Уникум-Центр, 1997. - 366 с.

9. Зверев, В. В. Русское народничество : учеб. пособие / В. В. Зверев. - М. : РАГС, 2009. - 285 с.

10. История России в XIX веке. - СПб. : А. и И. Гранат, 1911. - Т. 9. -267 с.

11. Карпович, М. М. Лекции по интеллектуальной истории России (XVIII - начало XX века) / М. М. Карпович. - М. : Русский путь, 2012. -351 с.

12. Корсаков, И. Заметки социалиста о текущем / И. Корсаков // Голос. - 1906. - 7 июня (№ 14).
13. Кривенко, С. По поводу культурных одиночек / С. Кривенко // Русское богатство. - 1893. № 12. - C. 160-192.

14. Лачаева, М. Ю. Исторические представления народников / М. Ю. Лачаева // Историография истории России до 1917 года : учеб. для студ. высш. учеб. заведений. В 2 т. - М. : ВЛАДОС, 2003. - Т. 2. C. 334-369.

15. Ленин, В. И. Полн. собр. соч. / В. И. Ленин. М. : Политиздат, 1967. - Т. 1. -662 с.

16. [Максимов, Е. Д.] Слобожанин М. К вопросу о культурной работе в ее историческом развитии / М. Слобожанин // Жизнь для всех. - 1909. Декабрь. - Стб. 41-56.

17. Меницкий, И. Народничество / И. Меницкий // Большая советская энциклопедия. - М. : ОГИЗ РСФСР, 1939. - Т. 41. - Стб. 170-186.

18. Мокшин, Г. Н. Идеи и жизнь «артельного человека» С.Н. Кривенко (1847-1906) : монография / Г. Н. Мокшин. - Воронеж : ВГУ, 2012. - 196 с.

19. Мокшин, Г. Н. Народники-культурники в отечественной историографии конца 1970-х 2000 -х гг. / Г. Н. Мокшин // Народники в истории России : Межвуз. сб-к науч. тр. - Воронеж : Научная книга, 2013. - Вып. 1. - С. 59-72.

20. Мокшин, Г. Н. Эволюция идеологии легального народничества в последней трети XIX - начале XX вв. : монография / Г. Н. Мокшин. - Воронеж : Научная книга, 2010. - 298 c.

21. Новак, С. Я. Я.В. Абрамов - пионер «теории малых дел» / С. Я. Новак // Отечественная история. -1997 . - № 4. - С. 80-85.

22. [Оболенский, Л. Е.] N. N. Возможно ли работать только для прогресса / N. N. // Мысль. 1880. - № 12. - C. 236-245.

23. Общественное движение в России в начале XX в. - СПб. : Товарищество «Общественная польза», 1909. - Т. 1. - $676 \mathrm{c}$.

24. Переписка Г. В. Плеханова и П. Б. Аксельрода. - М. : Издание Р.М. Плехановой, 1925. - Т. 1. $279 \mathrm{c}$.

25. Письмо Исполнительного комитета Александру III // Революционное народничество 70-х годов XIX века : сб. документов и материалов : в 2 т. М. ; Л. : Наука, 1964-1965. - Т. 2. - С. 191-195.

26. [Потресов, А. Н.] Старовер. Этюды о русской интеллигенции: сб. ст. / Старовер. - СПб. : Тип. акц. о-ва «Слово», 1906. -313 с.

27. Пыпин, А. Народничество / А. Пыпин // Вестник Европы. - 1884. - № 2. - С. 702-751.

28. Ткаченко, П. С. О спорных проблемах истории народничества / П. С. Ткаченко // История CCCP. -1963 . - № 6. - С. 76-84.

29. Троицкий, Н. А. Крестоносцы социализма: монография / Н. А. Троицкий. - Саратов : Изд-во Саратовск. ун-та, 2002. -372 с. 
30. Троцкий, Л. Д. Сочинения / Л. Д. Троцкий. - М. ; Л. : Госиздат, 1927. - Т. 21. - 520 с.

31. Харламов, В. И. Из истории либеральногонародничества в России в конце 70-х - начале 90-х годов XIX в. Общественно-политические воззрения Каблица (Юзова) : автореф. дис. ... канд. ист. наук / В. И. Харламов. - М., $1980 .-18 \mathrm{c}$.

32. Харламов, В. И. Из истории развития либерально-народнической мысли в пореформенной России [1982] / В. И. Харламов // «Будущего нет и не может быть без науки...» (памяти профессора Московского университета М.Г. Седова). - М. : МГУ, 2005. - С. 673-715.

33. Харламов, В. И. О периодизации истории либерального народничества в России (постановка вопроса, литература, задачи изучения) / В. И. Харламов // Проблемы истории СССР.-М. : Изд-во МГУ, 1979. Вып. 10. - С. 101-117.

34. Харламов, В. И. Публицисты «Недели» и формирование либерально-народнической идеологии в 70-х - 80-х годах XIX в. / В. И. Харламов // Революционеры и либералы России : сб. ст. - М. : Наука, 1990. - С. 163-185.

35. Ярославский, Е. История ВКП (б) / Е. Ярославский. - М. : Госиздат, 1926. - 392 с.

\section{REFERENCES}

1. Aptekman O.V. Zachatki kulturnogo narodnichestva $\mathrm{v} 70$-kh godakh (Kruzhok studentov zemledelcheskogo instituta) [The Beginnings of Cultural Populism in the 1970s (Circle of Students of the Agrarian Institute)]. Istoriko-revolyutsionnyy sbornik [Historical and Revolutionary Collection]. Moscow; Petrograd, Gosizdat Publ., 1924, vol. 1, pp. 9-36.

2. Aptekman O.V. Obshchestvo "Zemlya $i$ volya" 70-kh gg. Po lichnym vospominaniyam [Community "Land and Freedom" of the 1970s. Based on Personal Memories]. Petrograd, Kolos Publ., 1924. $460 \mathrm{p}$.

3. Baluev B.P. Liberalnoe narodnichestvo na rubezhe XIX-XX vekov [Liberal Populism at the Turn of the Nineteenth and Twentieth Centuries]. Moscow, Nauka Publ., 1995. 267 p.

4. Bogdanovich A.I. Nasushchnyy vopros [The Urgent Issue]. London, London Edition Fund Free Russian Press, 1895. 32 p.

5. Budnitskiy O.V. Terrorizm v rossiyskom osvoboditelnom dvizhenii: ideologiya, etika, psihologiya (vtoraya polovina XIX veka) [Terrorism in the Russian Liberation Movement: Ideology, Ethics, Psychology (Second Half of the 19th)]. Moscow, ROSSPEN Publ., 2000. 399 p.

6. Bush V.V. Ocherki literaturnogo narodnichestva 70-80-kh gg. [Essays on Literary Populism in 1970-1980s].
Moscow; Leningrad, Khudozhestvennaya literature Publ., 1931.162p.

7. Gordeeva I.A. "Zabytye lyudi". Istoriya rossiyskogo kommunitarnogo dvizheniya ["Forgotten People". The History of Russian Communitarian Movement]. Moscow, AIRO-XX Publ., 2003. 240 p.

8. Zverev V.V. Reformatorskoe narodnichestvo $i$ problema modernizatsii Rossii. Ot sorokovykh $k$ devyanostym godam XIXv. [Reformist Populism and the Problem of Russia's Modernization. From the 1840s to the 1890]. Moscow, Unikum-Tsentr Publ., 1997. 366 p.

9. Zverev V. V. Russkoe narodnichestvo: Uchebnoe posobie [Russian Populism: Tutorial]. Moscow, RAGS Publ., 2009. 285 p.

10. Istoriya Rossii v XIX veke [History of Russia in the 19th Century]. Saint Petersburg, A. and I. Granat Publ., 1911, vol. 9. 267 p.

11. Karpovich M.M. Lektsii po intellektualnoy istorii Rossii (XVIII-nachalo XX veka) [Lectures on the Intellectual History of Russia (18th - the Beginning of the 20th Century)]. Moscow, Russkiy put Publ., $2012.351 \mathrm{p}$.

12. Korsakov I. Zametki sotsialista o tekuspchem [Socialist's Notes on the Current]. Golos, 1906, no.14, June 7.

13. Krivenko S. Po povodu kulturnykh odinochek [On the Cultural Singles]. Russkoe bogatstvo, 1893, no. 12, pp. 160-192.

14. Lachaeva M.Yu. Istoricheskie predstavleniya narodnikov [Historical Presentations of Populists]. Istoriografiya istorii Rossii do 1917 goda: Uchebnik dlya studentov vysshikh uchebnykh zavedeniy: $v 2 t$. [The Historiography of the History of Russia Before 1917: the Textbook for Students of Higher Educational Institutions: in 2 vols.]. Moscow, VLADOS Publ., 2003, vol. 2, pp. 334-369.

15. Lenin V.I. Polnoe sobranie sochineniy [Full Composition of Writings]. Moscow, Politizdat Publ., 1967, vol. 1. $662 \mathrm{p}$.

16. Maksimov E.D., Slobozhanin M. K voprosu o kulturnoy rabote $\mathrm{v}$ ee istoricheskom razvitii [On the Cultural Work in Its Historical Development]. Zhizn dlya vsekh, 1909, December, pp. 41-56.

17. Menitskiy I. Narodnichestvo [Populism]. Moscow, OGIZRSFSR Publ., 1939, vol. 41, pp. 170-186.

18. Mokshin G.N. Idei i zhizn "artelnogo cheloveka" S.N. Krivenko (1847-1906): monografiya [Ideas and Life of "Artisanal Man" S.N. Krivenko (1847-1906): Monograph]. Voronezh, VGU Publ., 2012. $196 \mathrm{p}$.

19. Mokshin G.N. Narodniki-kulturniki v otechestvennoy istoriografii kontsa 1970-2000 gg. [Populists-Culturalists in the National Historiography of the Late 1970s-2000s.]. Narodniki v istorii Rossii [Populists in the History of Russia]. Voronezh, Nauchnaya kniga Publ., 2013, vol. 1, pp. 59-72. 
20. Mokshin G.N. Evolyutsiya ideologii legalnogo narodnichestva $v$ posledney treti XIX nachale $X X v v$. [The Evolution of the Legal Populism Ideology in the Last Third of the 19th - Early 20th Centuries]. Voronezh, Nauchnaya kniga Publ., 2010. $298 \mathrm{p}$.

21. Novak S.Ya. Ya.V. Abramov - pioner "teorii malykh del" [Ya.V. Abramov - Pioneer of the "Theory of Small Deeds"]. Otechestvennaya istoriya, 1997, no. 4 ,pp. $80-85$.

22. Obolenskiy L.E. Vozmozhno li rabotat tolko dlya progressa [Is It Possible to Work Only for Progress]. Mysl, 1880, no. 12, pp. 236-245.

23. Obshchestvennoe dvizhenie v Rossii v nachale $X X v$. [Social Movement in Russia at the Beginning of the 20th Century: in 2 vols. Vol. 1]. Saint Petersburg, Tovarishchestvo "Obshchestvennaya polza", $1909.676 \mathrm{p}$.

24. Perepiska G.V. Plehanova i P.B. Akselroda [Correspondence of G.V. Plekhanov and P.B. Axelrod]. Moscow, Izdanie R.M. Plekhanovoy, 1925, vol. 1. 279 p.

25. Pismo Ispolnitelnogo komiteta Aleksandru III [Letter of the Executive Committee to Alexander III]. Revolyutsionnoe narodnichestvo 70-kh godov XIX veka: sbornik dokumentov $i$ materialov: $v 2$ t. T. 2 [The Revolutionary Populism of the 1870s: Collection of Documents and Materials: in 2 vols. Vol. 2]. Moscow; Leningrad, Nauka Publ., 1964-1965, vol. 2, pp. 191-195.

26. Potresov A.N. Starover. Etyudy o russkoy intelligentsii: sbornik statey [Old Believer. Essays on the Russian Intellectuals: Collection of Articles]. Saint Petersburg, Slovo Publ., 1906.313 p.

27. Pypin A. Narodnichestvo [Populism]. Vestnik Evropy, 1884, no. 2, pp. 702-751.

28. Tkachenko P.S. O spornykh problemakh istorii narodnichestva [On the Controversial Issues of Populism History]. Istoriya SSSR, 1963, no. 6, pp. 76-84.
29. Troitskiy N.A. Krestonostsy sotsializma: monografiya [Crusaders of Socialism: Monograph]. Saratov, Izd-vo Saratovskogo un-ta, 2002. $372 \mathrm{p}$.

30. Trotskiy L.D. Sochineniya [Works]. Moscow; Leningrad, Gosizdat Publ., 1927, vol. 21. 520 p.

31. Kharlamov V.I. Iz istorii liberalnogo narodnichestva $v$ Rossii $v$ kontse 70 - nachale 90 godov XIX v. Obshchestvenno-politicheskie vozzreniya Kablitsa Yuzova: avtoref. dis. ... kand. ist. nauk [From the History of Liberal Populism in Russia in the late 1870s-early 1890s s Socio-Political Views of Kablitz Yuzov. Cand. Hist. sci. abs. diss.]. Moscow, 1980. $18 \mathrm{p}$.

32. Kharlamov V.I. Iz istorii razvitiya liberalnonarodnicheskoy mysli v poreformennoy Rossii (1982) [From the History of Liberal-Populist Ideas in the PostReform Russia (1982)]. "Budushchego net i ne mozhet byt bez nauk...» (Pamyati professora Moskovskogo universiteta M.G. Sedova) ["The Future Cannot Exist Without Sciences..." (In Memory of M.G. Sedov, Professor of Moscow University)]. Moscow, MGU Publ., 2005, pp. 673-715.

33. Kharlamov V.I. O periodizatsii istorii liberalnogo narodnichestva v Rossii (Postanovka voprosa, literatura, zadachi izucheniya) [On the Periodization of the History of Liberal Populism in Russia (The Question, Literature, the Taska of Studying)]. Problemy istorii SSSR [Problems of the History of the USSR]. Moscow, MGU Publ., 1979, vol. 10, pp. 101-117.

34. Kharlamov V.I. Publitsisty "Nedeli" i formirovanie liberalno-narodnicheskoy ideologii v 70-80 godakh XIX v. [Publicists of the "Week" and the Formation of the LiberalPopulist Ideology in the 1870-1880s]. Revolyutsionery $i$ liberaly Rossii [Russian Revolutionaries and Liberals]. Moscow, Nauka Publ., 1990, pp. 163-185.

35. Yaroslavskiy E. Istoriya VKP (b) [History of the CPSU (b)]. Moscow, Gosizdat Publ., 1926. 392 p. 